\title{
FLUCTUATION IN THE LEVEL OF THE CASPIAN SEA AND ITS CONSEQUENCES
}

\author{
Akimgali Kenzhegaliev ${ }^{1}$, Assylbek Kanbetov ${ }^{1}$, Dauren Kulbatyrov ${ }^{1}$, Aiauzhan Shakhmanova ${ }^{1}$, and Ainagul Abilgaziyeva ${ }^{1}$ \\ ${ }^{1}$ Non-profit JCS «Atyrau university of oil and gas named after Safi Utebayev»
}

\begin{abstract}
While in the early neogene, tectonic and to a lesser extent climatic factors impacted on the sea level, at the present stage climatic, man-made and anthropogenic factors are at the forefront. As a result of an increase in the level of the Caspian Sea by more than $2.4 \mathrm{~m}, 35-40$ thousand square meters $\mathrm{km}$ of territory was flooded, during the flooding and flooding of the coastal territory for the period 1978-1995 led to a change in natural, socio-economic and medico-ecological conditions. The consequences of rising sea levels led to the resettlement of about 100 thousand people living in the coastal flooded zone of the Northern Caspian Sea and many industrial facilities.
\end{abstract}

\section{Introduction}

By the end of 1977, the sea level dropped to the lowest level in 500 years - minus $29.0 \mathrm{~m} \mathrm{BS}$, as a result of which the territory of 48 thousand $\mathrm{km} 2$ exceeding the territory of states like Denmark and Estonia drained [1]. To prevent a catastrophic drop in sea level at that time, many projects were being developed, the purpose of which was to prevent a further drop in level by either replenishing the surface inflow of river waters or reducing the total evaporation from the sea and flowing into the Gulf of Kara-Bogaz-Gol.

Sudden and sharp rise in the level in 1978 led to even more dramatic consequences than its fall, since the economy and population of coastal areas had already adapted to low sea levels.

The increase in the level has led to a change in the natural, socio-economic and medico-ecological conditions of coastal areas during their flooding and waterlogging. All this caused the resettlement of a significant part of the population from flood zones. In the Northern Caspian only, it affected dozens of settlements, of which about 100 thousand people were resettled and many industrial facilities were displaced. The area of flooded territories amounted to 35-40 thousand $\mathrm{km} 2$ or an equivalent area of the states of Belgium or Moldova.

One of the important problems of the Caspian Sea is the problem of sea level change and the forecasting of such changes.

In view of the above, we were faced with the task of studying the causes of such sharp fluctuations in sea level, especially in its northern part, where hydrocarbon deposits are intensively developed.

The studies were carried out by the cameral method.

\section{Results and discussions}

The authors in their work [2] argue that the level of the Caspian Sea will continue to fluctuate within the multiyear absolute elevations of minus 26 - minus $33 \mathrm{~m}$, close to the coastline, as in 1977.

Researchers drew attention to the instability of the level regime of the Caspian Sea long ago, the German naturalist and traveler A. Humboldt, who visited the Caspian Sea in 1829 [3], hypothesized that the cause of sea level fluctuations is the periodic repetition of very dry and very wet years. His compatriot Pallas, who led the expedition of the St. Petersburg Academy of Sciences in the central region of Russia in 1768-1774, including the Caspian Lowland, pointed out the dependence of UKM fluctuations on hydrometeorological factors: air temperature, wind, the amount of atmospheric precipitation and the amount of water brought by rivers. This problem gained particular importance in the twentieth century as a result of a significant drop in the level by more than $3 \mathrm{~m}$ from 1929 to 1977 , and then its equally significant rise by $2.4 \mathrm{~m}$ from 1978 to 1995 [4].

The work [5] notes a change in the hydrometeorological and hydrodynamic regimes of the Caspian Sea, which is influenced by both natural and anthropogenic factors, which is one of its main distinguishing features.

The conduct of economic activities on the coastal zone of the sea, along with changes in sea level, is negatively affected by short-term catching-up phenomena [4].

While the biological resources of the Caspian Sea were of particular importance and interest before the 90 , after the 90 of the last century, interest in the mineral resources of the sea by the sovereign states of the coastal 
zones of the Caspian Sea turned out to be preferable $[5,6]$.

Sea-level changes pose considerable problems in natural and economic activities, both socio-economic and ecological, especially in shipping and fishing, both in the coastal zone and estuaries of rivers and on the high seas.

Changes in the level of the Caspian Sea lead to noticeable changes in the coastline of the shallow Northern Caspian Sea: over a more than 100-year period, the movements of the coastline in certain sections of the coast reached several tens of kilometers [7] (Figure 1).

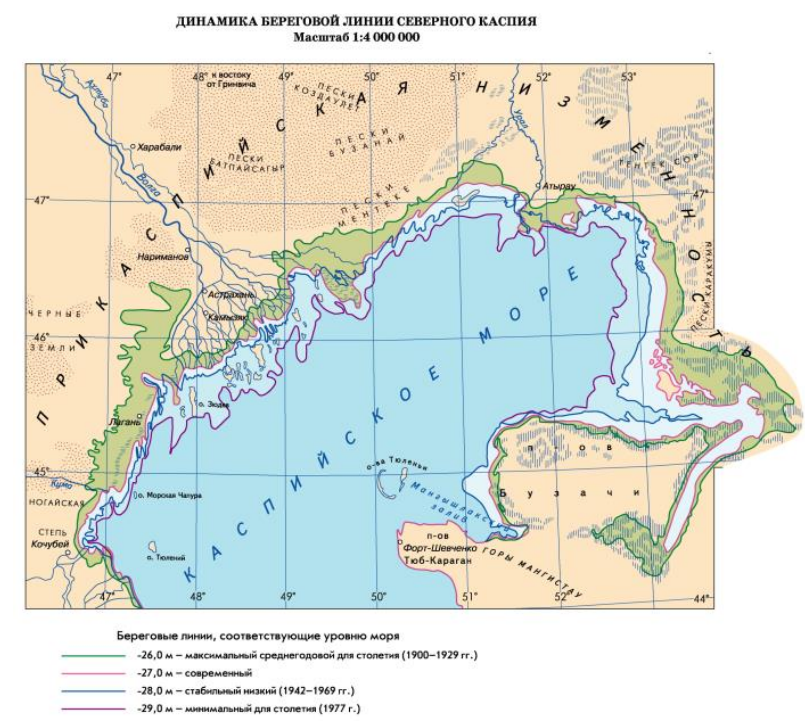

Fig. 1. The North Caspian coastline dynamics at sea levels $26.0 ;-27.0 ;-28.0$ and $-29.0 \mathrm{~m}$ (in BS).

The authors [8] cite a space image (figure 2) that with the modern level of the Caspian - $28 \mathrm{~m}$ BS, the narrow and long Kaidak Bay and, to a large extent, Dead Kultuk Bay (the former Komsomolets Bay and even earlier - Tsesarevich Bay) dry up.

Since the Caspian is a closed basin, changes in its level are determined mainly by river runoff, precipitation, evaporation, and runoff to the Kara-BogazGol Bay [9]. According to some authors [10], the reason, or rather the source of the fluctuation in the level of lakes, is the sections of bottom sediments, each layer of which is lithological and geochemical features, the composition of fauna, mollusks, microfauna, diatomaceous algae, etc., reflects certain parameters of the feature that was observed in the sea during its accumulation. Along with these, the author argues that solar activity influences the fluctuation in the level of closed reservoirs, table 1 provides data on the dependence of level rise or level decrease on sun activity.
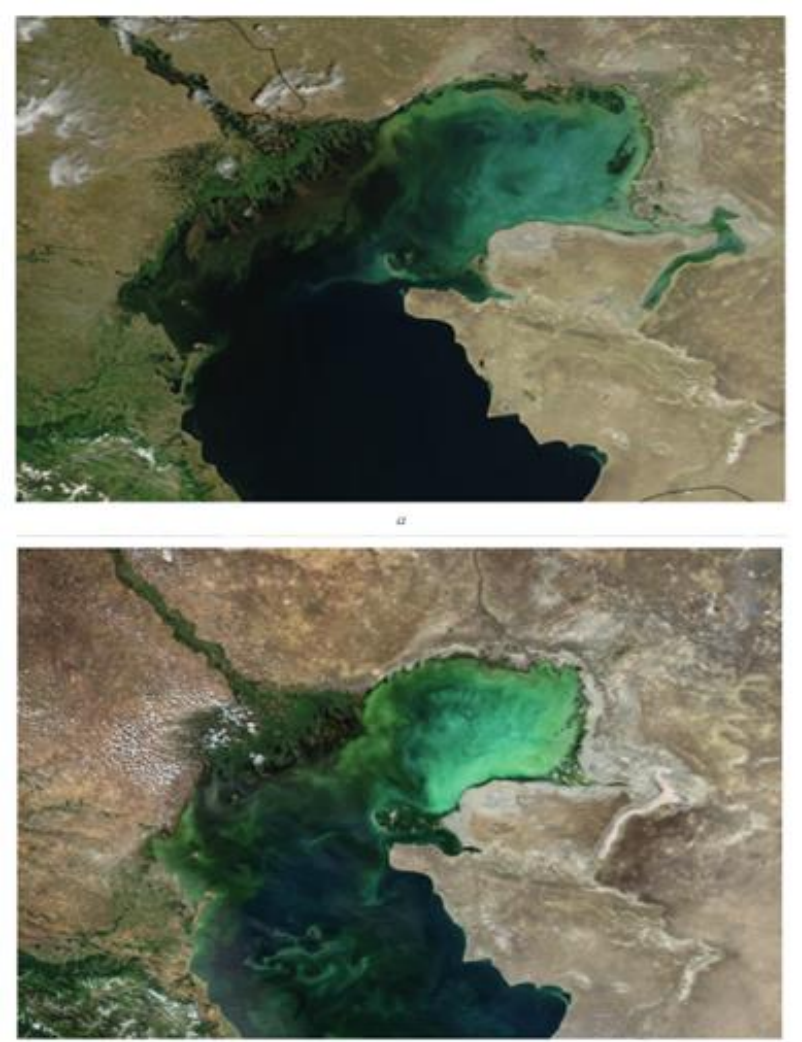

Fig. 2. Fragments of images MODIS-Aqua: a - 11.06.2005 (sea level - 26.7 m); b - 03.08.2017 (sea level - $28.0 \mathrm{~m}$ ).

For example, when comparing fluctuations in lake levels with solar activity cycles, it was found that when solar activity increases, lake levels decrease, and when weakens, they increase (Table 1).

Table 1. The effect of solar activity on fluctuations in the levels of lakes [10].

\begin{tabular}{|c|c|c|c|}
\hline Years & Balkhash & Aral & Caspian \\
\hline $\begin{array}{c}1900- \\
1910\end{array}$ & Level increase & Level increase & $\begin{array}{c}\text { Level } \\
\text { increase }\end{array}$ \\
\hline $\begin{array}{c}1911- \\
1920\end{array}$ & Level decrease & Level & $\begin{array}{c}\text { Level } \\
\text { decrease }\end{array}$ \\
\hline 1921 & Level increase & Level increase & $\begin{array}{c}\text { Level } \\
\text { decrease }\end{array}$ \\
\hline $1922-$ & Level decrease & Level & $\begin{array}{c}\text { Level } \\
\text { increase }\end{array}$ \\
\hline 1930 & & decrease & Level \\
1931 & Level increase & Level increase & \\
& & & \\
\hline
\end{tabular}

Survived descriptions of ancient authors and a geomorphological analysis of the coast of this area were used In the Middle Ages to study the Caspian Sea. A significant role was played by the analysis of materials related to the underwater continuation of the Derbent fortress. Its remains are traced for several hundred meters under water to a depth of 4-7 $\mathrm{m}$ [11].

In addition, short-term changes in sea level are influenced by overtaking phenomena [12].

Changes in the level of the Caspian Sea are mainly due to climatic and geological processes, the latter include tectonic processes leading to changes in the size of the basin and the sediments that fill it. Whereas the climatic process is responsible for the water balance of 
the sea [13], which occurs due to the submarine unloading of groundwater absorbed during the stretching or compression of the pallet layers of the sea. The share of influence on the process of sea level fluctuation due to filling the depression with precipitation is negligible.

In work [14], the authors believe that the lowering of sea level has led to a fundamental transformation of the shores and desertification of coastal areas. This led to a decrease in groundwater levels and the accompanying significant changes in the Caspian ecosystem, as well as the efficiency of the marine fleet and fisheries, especially in the shallow northern part of the sea.

As a result of the fall of sea level in 1977, the coastline of the northeastern part of the Caspian Sea retreated by $120-140 \mathrm{~km}$, which negatively affected the oil industry of the economy and the development of hydrocarbon raw materials in the shelf zone. As a result, problems arose in navigation on the lower reaches of rivers flowing into the sea, the approach routes to ports shallowed, and difficulties appeared for passage to the Volga-Caspian Sea Shipping Channel.

130 large and small rivers flow into the Caspian Sea, supplying it with about 300 cubic meters. $\mathrm{km}$ of water annually [15]. The largest of them: Volga, Terek, Samur, Sulak (Russia), Ural, Emba (Kazakhstan), Kura (Azerbaijan), Atrek (Turkmenistan), Sefidrud (Iran), etc. $88-90 \%$ of the water entering the sea, falls on the Volga, Ural, Terek and Sulak. Their total water flow is about 215-224 km3/year. Table 2 shows the characteristics of the main rivers of the Caspian basin.

Table 2. Modern hydrographic characteristics of the main rivers flowing into the Caspian Sea [16].

\begin{tabular}{|c|c|c|}
\hline River & River length, km & $\begin{array}{c}\text { Area of basin, thous } \\
\text { and km }\end{array}$ \\
\hline Volga & 3530 & 1360 \\
\hline Ural & 2430 & 237 \\
\hline Terek & 623 & 43.2 \\
\hline Sulak & 169 & 15.2 \\
\hline Kura & 1360 & 188 \\
\hline
\end{tabular}

Sea level changes can be of two types. The first type includes the so-called eustatic changes. These include age-old, perennial, annual and seasonal fluctuations reflecting changes in the volume of sea waters, the intensity of which is not determined by the constancy of the water balance.

The second type includes non-periodic fluctuations in the level due to subliming phenomena due to the action of the wind and affecting only the redistribution of water masses along the sea. The above types of fluctuations in the complex create a complex temporal-spatial mode of sea level.

Many studies are devoted to the centuries-old and centuries-old variability of the level of the Caspian Sea [17]. As noted above, there are many opinions regarding centuries-old fluctuations in the level of the Caspian Sea. On the one hand, global geological processes are responsible for the formation of the level of the Caspian Sea, and on the other, regional climatic features [18, 19].

In addition to these, as noted above, the MCC depends on river flow, evaporation, precipitation, etc., which affects the circulation of the atmosphere. The circulation of the atmosphere depends on many factors, the most important of which is the radiant energy of the Sun, which is unevenly distributed throughout the globe, and this in turn is the cause of global circulation. In the distribution of annual precipitation and evaporation over the northern hemisphere and its individual zonal regions, large-scale circulation processes form climatic and weather conditions $[20,21]$.

\section{Conclusion}

Based on the above, it should be noted that in the early neogene, tectonic and to a lesser extent climatic factors had predominant influence on the sea level, then at the present stage climatic, man-made and anthropogenic factors are at the forefront.

As a result of sea level rise of more than $2,4 \mathrm{~m}$ in the period of 1978-1995, flooding and flooding of the coastal territory occurred (35-40 thousand square kilometers of the territory were flooded), which led to a change in natural, socio-economic and medicoecological conditions. About 100 thousand people were resettled from the coastal flooded zone of the Northern Caspian Sea and many industrial facilities were displaced

It is possible to preserve the biodiversity and biological resources of the Caspian Sea and prevent the negative consequences of fluctuations in the level, if we take into account changes in the natural conditions in the field of risk of the coastal zone from -20 to -34 meters of absolute height when conducting economic activities.

- In addition to its role in the economy of coastal states, the Caspian Sea is of international importance from an environmental point of view, in terms of maintaining the biodiversity of the biosphere and preserving unique biological resources. In addition, more recent attention has been paid to the development of promising oil and gas fields.

- The role of sediment accumulation in sea level fluctuation is incredible;

- Underground communication with other seas is incredible phenomenon too;

\section{References}

1. G.I. Rychagov. Fluctuations in the level of the Caspian Sea: Causes, consequences, forecast // Vestn. Moscow un-that ser. 5. Geography. 2011. No. 2, p.4-12

2. Sakinat A. Guseinova, Akhma S. Abdumasadov.The forecast of Caspian Sea level dynamics and its consequences for coastal areas //YugRossii: Ekologia, razvitie. 2015, Volume 10. No. 4, pp.119126.

3. https://litrus.net/book/read/59544? $\mathrm{p}=7$

4. Water balance and fluctuations in the level of the Caspian Sea. Modeling and forecasting. Edited by Dr. Geogr. of sciences E.S. Nesterova - M.: TriadaLTD, 2016. - p. 378. 
5. Zonn I.S., Zhiltsov S.S. New Caspian: geography, economy, politics. - M.: AST Vostok-Zapad, 2008. p. 542 .

6. Kenzhegaliyev A. Anthropogenic load of offshore oil exploration works on the environment of the Caspian Sea and methods of its reduction: Monograph. A.Kenzhegaliyev, Almaty: Gylym, 2010, p. 180

7. https://geographyofrussia.com/morya-rossiikaspijskoe-more/

8. A. I. Ginzburg, A. G. Kostyanaya Trends in changes in the hydrometeorological parameters of the Caspian Sea in the modern period (1990s2017)//Modern problems of remote sensing of the Earth from space. 2018. T. 15. No. 7. pp.195-207.

9. file:///C:/Users/User/Downloads/abuz_ne.pdf

10. Tabelinova A.S. Fluctuation in the level of the Caspian Sea: causes, consequences and research methods//Eurasian Union of Scientists (ESU). 2019, No. 4 (61), pp.34-40.

11. K.A. Sabanaev V.I. Cherkashin Geological structure and oil and gas content of the sedimentary complex of the Russian sector of the Caspian Sea. Makhachkala. 2008, p.208.

12. E.A. Zakarin, L.A. Balakay, T.V. Dedova. Modeling of hydrodynamics of the Northern Caspian Sea Proceedings of the International Conference "Mathematical and Physical Methods in Ecology and Monitoring of the Natural Environment". Moscow, October 23-25, 2001, Ed: Moscow State University, 2001, pp.92-96

13. V.V. Kovalev, S.G. Parada. Geological aspects of modern changes in the level of the Caspian Sea//Bulletin of the Southern Scientific Center. Volume 9, No. 2, 2013, pp. 38-46

14. Bukharitsyn P.I., Politov S.A., Lukyanov Yu.S. The influence of fluctuations in the level of the Caspian Sea on the economic development of the coastal part of the Astrakhan region//Works of the GOIN, 2008. - Volume 211, pp. 460-466.

15. https://1news.az/news/kolebaniya-urovnyakaspiyskogo-morya-i-ih-posledstviya

16. Mouths of rivers of the Caspian region: the history of formation, modern hydrological and morphological processes and dangerous hydrological phenomena. Edited by V.N. Mikhailova. - M.: GEOS, 2013, p. 703.

17. Abuzyarov Z.K., Nesterov E.S. Some features of spatio-temporal variability of the level of the Caspian Sea//Proceedings of the Hydrometeorological Center of Russia, 2011, Edition 345, pp. 5-23.

18. Gul K.K. Century-old fluctuations in the level of the Caspian Sea// Pub. ANAzSSR. Series of Earth Sciences. - 1972. - No. 3. pp. 81-83.

19. Berg L.S. Caspian Sea level in historical time//Problems of physical geography, 1934, T. 1. Volume 1, pp. 11-64
20. Butaev A.M. Caspian: Riddles of the Makhachkala level, 1998, 70 p. 59.

21. Monakhov S.K., Romanov N.T. Dynamics of Caspian Sea-level fields and seismic activity of the Eastern Caucasus and the Caucasus//Bulletin of the DNC RAS. - 1999, No. 5, pp. 40-45. 